\title{
Laparoscopic partial nephrectomy in warm ischemia: impact of parenchymal loss on kidney function
}

\author{
Fariborz Bagheri MD², Csaba Pusztai MD1, László Farkas MD¹, István Buzogány MD³,

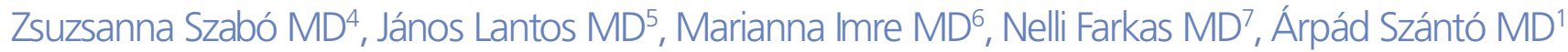 \\ 'University of Pécs Medical School, Department of Urology, Pécs, Hungary (director: Árpád Szántó MD) \\ 2Dubai Health Authority, Dubai Hospital, Department of Urology, Dubai, UAE \\ 3Péterfy Sándor Street Hospital, Department of Urology, Budapest, Hungary (director: István Buzogány MD) \\ ${ }^{4}$ University of Pécs Medical School, Department of Nuclear Medicine, Pécs, Hungary (director: Katalin Zámbó MD) \\ [University of Pécs Medical School, Department of Research and Techniques, Pécs, Hungary (director: Gábor Jancsó MD) \\ ${ }^{6}$ Diagnostic Center of Pécs, Hungary (director: Ferenc Kövér MD) \\ 'University of Pécs Medical School, Institute of Bioanalysis, Pécs, Hungary \\ (director: Ferenc Kilár MD)

Contact:
Fariborz Bagheri MD
email: bafariborz@hotmail.com

\section{SUMMARY}

Objective: To evaluate impact of deliberate renal parenchymal loss on renal function, distinguished from ischemic-reperfusion (I-R) injury after laparoscopic partial nephrectomy (LPN) under warm ischemia (WI).

Patients and methods: Thirty five patients with a single polar renal mass $\leq 4 \mathrm{~cm}$ with normal contralateral kidney planned for transperitoneal laparoscopic partial nephrectomy (LPN) under WI using en-bloc hilar occlusion in a prospective study. Total differential renal function (T-DRF) using 99TTc-Dimercaptosuccinic acid (99TTc-DMSA) was evaluated preoperatively and postoperatively in different intervals over one year. In all isotope assessments, a special region of interest (ROI) was selected on the non-tumorous pole of the involved kidney and it was compared with the same ROI in the contralateral kidney. This was named as partial DRF (P-DRF). Any postoperative decline in the P-DRF of the operated kidney was contributed to I-R injury unrelated to parenchymal loss. Subtraction of the P-DRF decline from the T-DRF decline was attributed to the parenchymal loss caused by deliberate resection and suturing of the normal parenchyma. Other than DRF, serum creatinine $(\mathrm{s} C \mathrm{C})$, estimated glomerular filtration rate (eGFR) using Chronic Kidney Disease Epidemiology Collaboration (CKD-EPI) equation, warm ischemia time (WIT), and weight of the resected specimen were also measured.

Results: The mean WIT was 22 minutes, and the mean weight of resected specimen was 18 grams. The mean postoperative eGFR declined to 87 from its baseline mean value of 97 ( $p$-value $=0.0757$ ). Mean postoperative T-DRF and P-DRF of the operated kidney, declined by $7 \%$ and $3 \%$ respectively.

\section{Laparoszkópos meleg iszkémiában végzett parciális nephrectomia: a parenchymavesztés hatása a vese- funkcióra}

\section{ÖSSZEFOGLALÁS}

Célkitüzés: A veseparenchyma-veszteség hatásának meghatározása a vesefunkcióra elkülönítve a reperfúzió károsodástól (I-R) meleg iszkémiában végzett parciális nephrectomia során.

Betegek és módszer: Tanulmányukba harmincöt, $\leq 4$ $\mathrm{cm}$ vesedaganat miatt meleg iszkémiában végzett transzperitoneális laparoszkópos parciális nephrectomián átesett, ellenoldali ép vesével rendelkező beteg került prospektíven beválasztásra. Meghatároztuk az egyes vesék funkcióját ${ }^{99 m T c-}$ Dimercaptosuccinic acid (99TmTc-DMSA) veseszcintigráfiával a műtét előtt, posztoperatíve és a nyomonkövetés során meghatározott időpontokban egy évig (Total differential renal function - T-DRF). Összehasonlítottuk a daganatos vese nem daganatos pólusának és az ellenoldali vese azonos lokalizációjú területének funkcióját ROI (region of interest) technikával (partial DRF - P-DRF). Az operált és nem operált vesék nem daganatos területeinek funkciójában észlelt csökkenés (P-DRF) a reperfúzió (I-R) hatásának volt betudható. A P-DRF és a T-DRT-csökkenés különbsége parenchymaveszteségnek tulajdonítható, amelyet a parenchyma-reszekció és varrat okozott. Ezen kívül vizsgáltuk a Se kreatinin értékek, a glomeruláris filtrációs ráta (eGFR) változását, a meleg iszkémiás időt (WIT) és az eltávolított veseszövet súlyát. Eredmények: Az átlagos meleg iszkémiás idő 22 perc, az eltávolított veseszövet súlya $18 \mathrm{~g}$ volt. A posztoperatív eGFRértéke átlagosan $87 \mathrm{ml} /$ perc volt a kiindulási átlagos 97 
Conclusion: After LPN of small renal mass, decline in renal function is primarily contributed to parenchymal loss caused by deliberate resection and suturing of the normal parenchyma rather than the I-R injury.

\section{KEYWORDS}

LAPAROSCOPY; PARENCHYMAL LOSS; RENAL FUNCTION; WARM ISCHEMIA, RENAL SCINTIGRAPHY, REPERFUSION $\mathrm{ml} /$ perchez képest ( $p$-value $=0,0757$ ). A posztoperatív T-DRF és P-DRF csökkenés átlaga 7\%, illetve $3 \%$ volt.

Megbeszélés: A laparoszkópos parciális nephrectomiát követően észlelt vesefunkció-csökkenés oka elsődlegesen a veseparenchyma-veszteség és varrat, az I-R szerepe lényegesen kisebb.

\section{KULCSSZAVAK}

LAPAROSZKÓPIA; VESEPARENCHYMA-VESZTESÉG; VESEFUNKCIÓ, MELEG ISZKÉMIA, VESESZCINTIGRÁFIA; REPERFÚZIÓ

lecting system closure and haemostasis. In all cases, the parenchymal defect was filled with one or two rolled Surgical bolsters. Parenchymal reconstruction was achieved by running 0 Vicryl sutures secured at each parenchymal exit by a Hemo-lok clip. The renal pedicle was released only after tumour excision and completion of renorrhaphy. At the time of hilar tourniquet release, $0.5 \mathrm{mg} / \mathrm{kg}$ of Furosemide injection was administered. The kidney was placed in its anatomic position and the Gerota's fascia was closed.

After extraction of the specimen, the surrounding fat tissues were detached and weight of the remaining resected mass was measured. The recorded parameters included the time for tumour resection, calyceal closure, haemostatic sutures and the total WIT.

Serum creatinine $(\mathrm{s} C \mathrm{r})$ was recorded and estimated glomerular filtration rate (eGFR) was calculated using chronic kidney disease epidemiology collaboration (CKD-EPI) equation (6). The above measurements were performed preoperatively (baseline), 5-6 hours after the surgery, on the $1^{\text {st }}, 3^{\text {rd }}$ and $7^{\text {th }}$ postoperative days and at the end of 1 ts $, 3^{\text {rd }}, 6^{\text {th }}$ and $12^{\text {th }}$ postoperative months.

In this study, in addition, 15 randomized patients treated with laparoscopic radical nephrectomy (LRN) were examined as a control group for our laboratory outcomes and all the above parameters were registered in this group.

\section{Renal scintigraphy}

In order to distinguish the impact of parenchymal loss from Wl effect on the operated kidney, we planned a novel method of investigation with renal scan as follow. All patients in LPN group underwent 99m Technetium-Dimercaptosuccinic Acid ( ${ }^{99 \mathrm{~m}} \mathrm{Tc}-\mathrm{DMSA}$ ) renal scintigraphy for the determination of split renal function preoperatively and at the end of $1^{\text {st }}$, $3^{\text {rd }} 6^{\text {th }}$ and $12^{\text {th }}$ postoperative months.

${ }^{99 m}$ Tc-DMSA isotope is a static renal agent and allows accurate calculation of differential renal function (DRF) (7). Since 99mTc-DMSA scan provides relative functional percentage of the two kidneys and the contralateral kidney served as a control for comparison after LPN, we selected patients with solitary small polar mass ( $\mathrm{T} 1 \mathrm{a})$, otherwise normal ipsilateral kidney, and normal contralateral kidney. Such selections have re- 


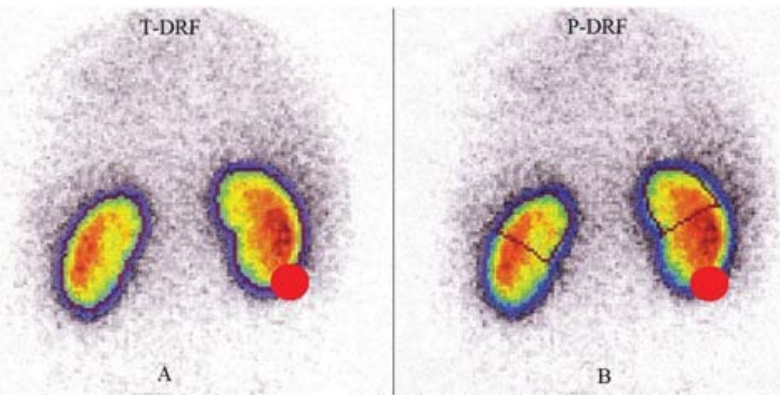

Figure 1: Renal SCINTIGRAPHY IS SHOWN WITH AN IMAGINARY TUMOUR IN THE LOWER POLE OF ONE KIDNEY (RED CIRCLE). A: The ROI IS SELECTEd (PURPLE LINE) tO DEMONSTRATE AND COMPARE THE T-DRF OF BOTH KIDNEYS. B: THE ROI IS SELECTED IN THE NON-TUMOROUS POLE OF THE INVOLVED KIDNEY AND COMPARED WITH THE SAME ROI IN THE CONTRALATERAL KIDNEY

sulted in a young cohort of patients with mean age of $50.5 \pm 11.9$ years old in our study.

\section{Assessment of total and partial differen- tial renal function}

\section{A novel approach}

Before the operation, all patients underwent radionuclide isotope examination performed by $99 \mathrm{mTc}$-DMSA. Renal scans were performed in supine position. Individual kidney uptake and differential renal function (DRF) percentage of left-toright kidneys were determined by the Patlak-Rutland method (8). The region of interest (ROI) of each kidney was determined with the use of an automated computer program drawing the ROI around the whole kidney. For processing purposes, all isotope results were saved in a computer program. This assessment which is a customary method of evaluating a static renal scan was called a "Total-DRF" (T-DRF) in our study (Fig. 1A).

By this means, in the tumorous kidney, the postoperative decline in percentage ratio, reflecting decrease in renal function, was considered as a consequence of both factors:

1. IR injury caused by length of WIT;

2. The kidney parenchymal volume reduction caused by removal of the tumour, and excision and suturing of the surrounding healthy tissues.

In an attempt to distinguish the impact of each of these two factors, we introduced a novel method which is referred as "Partial-DRF" (P-DRF). For this reason, in the preoperative renal scans, the exact location of the tumour was determined and only small polar masses (either upper or lower pole mass) were selected for the study. In the tumorous kidney, a region in the tumour-free pole was selected and manually a $\mathrm{ROI}$ was drawn in that pole. Identical ROI was selected in the same pole of the contralateral kidney (Fig. 1B). The same ROI drawing was used in all follow-up studies of a given patient.
Table 1: Patient's demographics and operation RESULTS OF LPN

Number of enrolled patients 35

Reasons for patient exclusion

(number of patients):

conversion to open partial

nephrectomy

continues moderate bleeding

from the resected site during

WIT

one of two accessory arteries

were clipped for safe resection

early postoperative bleeding

and selective arterial

embolization

missed more than one follow-

up appointment

Number of patients included

in statistical analysis

Male/female ratio $\quad 16 / 12$

Patient's age (years) $\quad 50.5 \pm 11.9$ (range: 23-74)

Body mass index 27.6 24.3 (range: 19.7-39)

Right/left ratio 12/16

Tumor greatest dimension

( $\mathrm{mm}$ ) by CT Scan

$26.4 \pm 6.4$ (range: $18-40$ )

PADUA classification of tumors 7 (range: 6-10)

Surgery indication:

relative 17

elective 11

absolute 0

Operative time (min) 145 \pm 35 (range: 95-245)

Time used for tumor $\quad 4.8 \pm 1.5$ (range: $2.5-10$ )

resection (min)

Time used for internal

sutures (min)

$9.6 \pm 3.5$ (range: $5-18$ )

Warm ischemia time (min)

Weight of the resected

specimen (gm)

$22 \pm 5.3$ (range: $12-32$ )

$18 \pm 9.1$ (range: 6-40)

Histopathology results:

RCC, Conventional type $\quad 19$ (68\%)

RCC, Chromophobe type $\quad 2(7 \%)$

RCC, Papillary type $\quad 4(14 \%)$

Oncocytoma $2(7 \%)$

Angiomyolipoma $\quad 1(4 \%)$

Positive Surgical Margins None

PADUA: Preoperative aspects and dimensions used for an anatomical classification of renal tumours; RCC: Renal cell carcinoma; WIT: Warm ischemia time 
Accordingly, P-DRF which reflects DRF of the intact pole of the operated kidney, which is affected only by the IR injury, was compared with the same pole on the contralateral kidney. The same processing was applied for all patients in all isotope scan examinations. As a result, in the postoperative isotope scans, with the P-DRF, we could compare an intact part of the operated kidney which was impacted by WI but not affected by parenchymal volume reduction with an identical segment of the normal contralateral kidney.

Any postoperative decline in the P-DRF of the operated kidney was considered as the renal functional loss resulted from IR injury only.

All renal isotope tests were evaluated and reported by same specialist doctor in nuclear medicine.

\section{Patient selection and statistical evaluations}

Any factor which could unpredictably influence on the WI consequence or the renal function outcome was excluded from the statistical assessments. Accordingly, one patient was excluded due to conversion to open partial nephrectomy. One patient was excluded due to continuous moderate bleeding from the resected site during $\mathrm{WI}$ time. In one patient with two accessory renal arteries, we had to clip one of the arteries for safe resection. In one case, five days after the operation, selective segmental arterial embolization of the operated kidney was applied due to arteriovenous shunt. Three patients were disqualified for statistical analysis since they missed more than one cycle of post-operative followups. Consequently, 28 patients were enrolled in the final statistical analysis. Demographics of the 28 patients and results of the operations are described in Table 1. The IBM SPSS version 20 (IBM Corp., Armonk, NY, USA) was used for the calculations and statistical analysis. ANOVA and Pearson product-moment correlation were calculated as deemed neces- sary. A p-value <0.05 was considered statistically significant. For further confirmation, a linear correlation coefficient was calculated for the assessment of a possible correlation of the T-DRF decline to the WIT in the operated kidney and to the mass of the resected specimen.

\section{Patients operated with laparoscopic radical nephrectomy}

In 15 patients with LRN selected for control group, the mean age was $61 \pm 12$ years (range: $41-78$ ). The male to female ratio was $11 / 4$, and right to left involved kidney ratio was 12/3. Their mean BMI was $29.7 \pm 5.4$ (range: 21.6-38.6), and the mean operative time was 153 minutes (range: 100-220). The mean age, BMI and the mean operative time were slightly higher than in the group of LPN.

\section{Results}

Twenty eight patients with small renal mass successfully underwent LPN and completed one year follow up according to our protocol. During operation, after hilar unclamping, in six patients we observed mild bleeding from the resected margin, which were resolved within 2-3 minutes by increasing pneumo-peritoneum or application of Surgical. We didn't have any significant bleeding, necessitate hilar re-occlusion. In our selected patients for statistical evaluations, major intra- or postoperative complication was not observed.

In the LPN group, the mean results of preoperative and postoperative renal function measured by serum creatinine ( $\mathrm{s} C r$ ), estimated glomerular filtration rate (eGFR, CKD-EPI equation) as described by Levey and colleagues (6) and total differential renal function (T-DRF) as well as partial differential renal function (P-DRF) are summarized in Table 2.

TAble 2: MeAn estimations of Kidney function Before AND AFTER LPN SURGery

\begin{tabular}{|c|c|c|c|c|c|c|c|c|c|}
\hline $\begin{array}{l}\text { Investigated } \\
\text { parameter and } \\
\text { normal ranges }\end{array}$ & $\begin{array}{c}\text { Preop } \\
\text { (base- } \\
\text { line) }\end{array}$ & $\begin{array}{c}1 \\
\text { day } \\
\text { post- } \\
\text { op }\end{array}$ & $\begin{array}{c}3 \\
\text { days } \\
\text { post- } \\
\text { op }\end{array}$ & $\begin{array}{c}7 \\
\text { days } \\
\text { post- } \\
\text { op }\end{array}$ & $\begin{array}{c}1 \\
\text { month } \\
\text { post- } \\
\text { op }\end{array}$ & $\begin{array}{c}3 \\
\text { months } \\
\text { post- } \\
\text { op }\end{array}$ & $\begin{array}{c}6 \\
\text { months } \\
\text { post- } \\
\text { op }\end{array}$ & $\begin{array}{c}12 \\
\text { months } \\
\text { post- } \\
\text { op }\end{array}$ & $\begin{array}{l}\text { Mean of } \\
\text { all post-op } \\
\text { results } \\
\text { after day } 1\end{array}$ \\
\hline $\begin{array}{l}\text { Serum creatinine } \\
(62-106 \mu \mathrm{mol} / \mathrm{l})\end{array}$ & $\begin{array}{c}71 \pm 14 \\
(44-94)\end{array}$ & $\begin{array}{c}86 \pm 22 \\
(43-120)\end{array}$ & $\begin{array}{c}82 \pm 20 \\
(42-124)\end{array}$ & $\begin{array}{c}82 \pm 16 \\
(50-112)\end{array}$ & $\begin{array}{c}80 \pm 16 \\
(43-103)\end{array}$ & $\begin{array}{c}79 \pm 17 \\
(47-108)\end{array}$ & $\begin{array}{c}80 \pm 17 \\
(40-98)\end{array}$ & $\begin{array}{c}82 \pm 16 \\
(50-111)\end{array}$ & $81(14 \% \uparrow)$ \\
\hline $\begin{array}{l}\text { eGFR (CKD-EPI) } \\
\left(>90 \mathrm{~mL} / \mathrm{min} / 1.73 \mathrm{~m}^{2}\right)\end{array}$ & $\begin{array}{c}97 \pm 17 \\
(55-122)\end{array}$ & $\begin{array}{c}81 \pm 21 \\
(44-114)\end{array}$ & $\begin{array}{c}87 \pm 20 \\
(55-117)\end{array}$ & $\begin{array}{c}85 \pm 18 \\
(60-106)\end{array}$ & $\begin{array}{c}87 \pm 18 \\
(49-114)\end{array}$ & $\begin{array}{c}90 \pm 21 \\
(48-124)\end{array}$ & $\begin{array}{c}87 \pm 20 \\
(54-120)\end{array}$ & $\begin{array}{c}86 \pm 20 \\
(48-116)\end{array}$ & $87(10 \% \downarrow \downarrow)$ \\
\hline $\begin{array}{l}\text { T-DRF of the } \\
\text { involved kidney (\%) }\end{array}$ & $\begin{array}{c}49 \pm 4 \\
(43-58)\end{array}$ & Not done & Not done & Not done & $\begin{array}{c}42 \pm 7 \\
(24-52)\end{array}$ & $\begin{array}{c}42 \pm 7 \\
(25-54)\end{array}$ & $\begin{array}{c}41 \pm 7 \\
(25-52)\end{array}$ & $\begin{array}{c}41 \pm 7 \\
(24-51)\end{array}$ & $42(7 \% \downarrow)$ \\
\hline $\begin{array}{l}\text { P-DRF of non- } \\
\text { tumorous pole of } \\
\text { involved kidney (\%) }\end{array}$ & $\begin{array}{c}50 \pm 4 \\
(44-59)\end{array}$ & Not done & Not done & Not done & $\begin{array}{c}47 \pm 6 \\
(37-57)\end{array}$ & $\begin{array}{c}48 \pm 5 \\
(37-55)\end{array}$ & $\begin{array}{c}46 \pm 4 \\
(35-52)\end{array}$ & $\begin{array}{c}47 \pm 4 \\
(38-54)\end{array}$ & $47(3 \% \downarrow)$ \\
\hline
\end{tabular}




\section{Evaluation of the renal function based on serum creatinine}

The detailed mean values of these tests are shown in Table 2 for LPN and Figure 2 for both LPN and LRN patients. In Figure 2 , the preoperative (time point 1) mean values of serum creatinine as well as the mean values at the eight postoperative check points is shown for both LPN and LRN groups. In LRN group we had elder population $(61 \pm 12$ years vs. $50.5 \pm 11.9$ years, $\mathrm{p}$-value $=0.008)$, more male to female ratio $(73 \% \mathrm{vs}$. $57 \%)$ and higher body mass index (BMI) $(29.7 \pm 5.4$ vs. $27.6 \pm 4.3, \mathrm{p}$-value $=0.18$ ). These data may explain the higher baseline $(84 \mu \mathrm{mo} / \mathrm{l})$ serum creatinine in the LRN group. It was a strong increase of serum creatinine level immediately after LRN with a peak on the $3^{\text {rd }}$ post-op day. It declined slightly and remained constantly high $(123 \mu \mathrm{mol} / \mathrm{l})$ until the end of first postoperative year. This reflects $\sim 46 \%$ rise in Se creatinine level compared to the baseline in LRN patients. In contrary, in the LPN group, the serum creatinine level was only slightly increased from $71 \mu \mathrm{mo} / / \mathrm{l}$ to $82 \mu \mathrm{mol} / \mathrm{I}(\sim 6 \%$ increase) during the first three postoperative days and remained constant until the end of observation.

\section{Evaluation of the renal function based on estimated GFR}

As shown in Table 2 and Figure 3, the mean preoperative or baseline eGFR of patients treated with LPN was 97+17 (range: 55-122) which decreased to $81 \pm 21$ (range: 44-114) in the 1st postoperative day ( $p$-value $=0.0069$ ). This shows a $16 \%$ decline in average eGFR which was the largest postoperative drop within one year of follow up. Conventionally, we call it "transient-state" of kidney function deterioration. In the 3rd postoperative day, we observed a $7 \%$ recovery in the average eGFR comparing to the 1st day. Although, due to the large deviations in the values, this tendency toward recovery was statistically insignificant ( $p$-value $=0.3821$ ). From the 3rd postoperative day to end of the study in $12^{\text {th }}$ month, the average eGFR remained roughly the same in both groups. Accordingly, for simplicity, average of all postoperative eGFR mean values after the transient-state (after the 1st day) were calculated and considered as the "steady-state" of renal function deterioration. This was $87 \mathrm{ml} / \mathrm{min} / 1.73 \mathrm{~m}^{2}$ in LPN patients which demonstrates $\sim 10 \%$ decrease in renal function comparing to the baseline ( $p$-value $=0.0757$ ).

As shown in Figure 4, the eGFR was lower for patients treated with LRN and showed a decrease during the first three postoperative days and thereafter remained at the same level. By this comparison, the difference in clinical parameter between the two groups as indicated above also should be taken into account.

It is worth to highlight that in the LRN control group, the average decline in the "steady state" of the kidney function was 40\% (81.34 declined to $\left.48.36 \mathrm{ml} / \mathrm{min} / 1.73 \mathrm{~m}^{2}\right)$.

In a simple explanation, we can conclude that, by removal of one whole kidney, nearly $40 \%$ of global kidney function declines, and by removal (resection) of one part of a kidney,

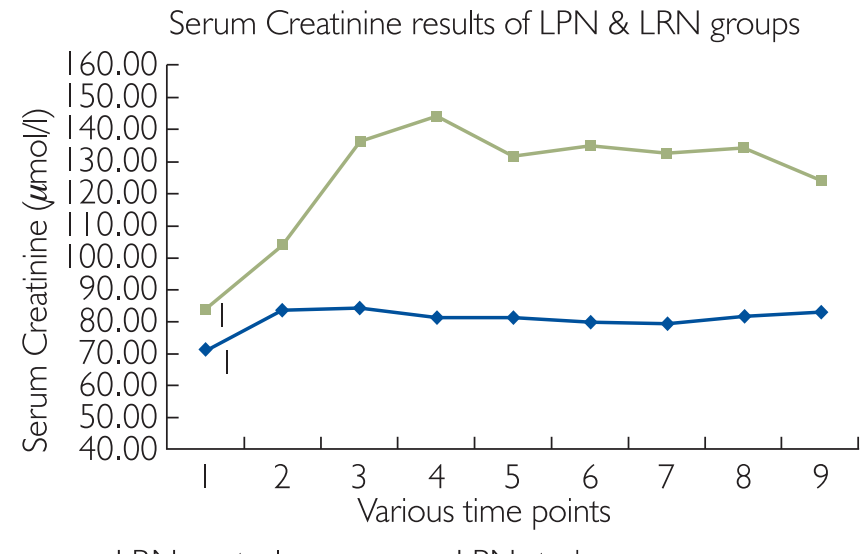

$=$ LRN control group $\rightarrow$ LPN study group

Figure 2: The CURVES Show the MEAN PREOPERATIVE (TIME POINT 1) SERUM CREATININE AND MEAN RESULTS OF POSTOPERATIVE SERUM CREATININE MEASURED IN PATIENTS WITH LRN AND LPN AT DIFFERENT TIME INTERVALS

(POINT 2: 5-6 HOURS POST-OP; POINT 3: $1^{\text {ST }}$ POST-OP DAY; POINT 4: $3^{\text {RD }}$ POST-OP DAY;

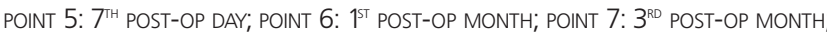
POINT 8: $6^{\text {TH }}$ POST-OP MONTH; POINT 9: $12^{\text {TH }}$ POST-OP MONTH)

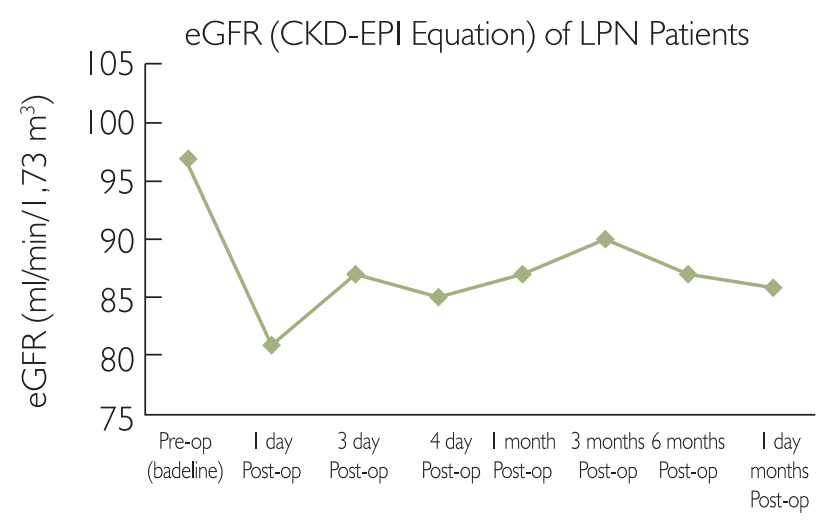

Figure 3: THE GRAPH SHOWS THE MEAN PREOPERATIVE AND POSTOPERATIVE EGFR VALUES IN THE STUDIED TIME INTERVALS FOR THE LPN PATIENTS ENROLLED IN THE STATISTIC EVALUATION

nearly $10 \%$ of the global kidney function decreases. Accordingly, parenchymal volume reduction after partial nephrectomy has a very important impact on outcome of kidney function and this should be certainly distinguished from the impact of the IR injury caused by WI.

\section{Impact of parenchymal volume reduction on the kidney function}

As seen in Table 2 and Figure 5, in the LPN study group, the mean preoperative or baseline T-DRF of the operated kidneys was $49 \%$ which is decreased to $42 \%$ on the 1 st postoperative month ( $p$-value $=0.001$ ). This value remained almost the same in the following time points. Repeated ANOVA measurements of all postoperative T-DRF did not show any significant alteration among them ( $p$-value $>0.6)$. Accordingly, av- 
erage of all postoperative T-DRF which was $42 \%$ was considered as the final postoperative result. On the other hand, the mean preoperative P-DRF of the intact pole of the operated kidney was $50 \%$ which decreased to $47 \%$ on the 1 st postoperative month ( $p$-value $=0.0727$ ). Average of all postoperative P-DRF was also $47 \%$ without any significant alteration among the time periods ( $p$-value $=>0.1)$.

Linear correlation coefficient was used to compare relationship of the T-DRF decline in the operated kidney to the mass of the resected specimen (Figure 6).

We have also used linear correlation coefficient to compare relationship of the T-DRF decline in the operated kidney to WIT (Figure 8). This showed a much stronger correlation between T-DRF decline and the resected mass comparing to the $\mathrm{W}$ lime ( $\mathrm{R} 2=0.7241$ and $\mathrm{p} 0.0837$ respectively).

\section{Discussion}

In 1950, Benjamin Abeshouse wrote "Few procedures provide the urologist with more satisfaction than those that preserve renal function" (9). While Abeshouse may have practiced urology prior to the availability of the strong data we now possess, his statement rings true to this day. On this principle, NSS has taken a prominent position at the helm of the treatment of renal tumours. Likewise, there has been continual progress toward resecting less and less renal parenchyma to preserve more renal function without sacrificing any of oncological rules.

There are several factors determining the postoperative renal function:

- A: the preoperative quality of renal function (underlying renal disease, limited glomerular function, etc.);

- B: the quantity of renal parenchyma remained after operation;

- C: the warm ischemia time.

The first factor can't be modified by surgical technique; the second is determined by the anatomical size and location of the tumour. The warm ischemia time is influenced by the experience of the surgeon and the operation technique applied. We planned a prospective study in order to distinguish the impact of parenchymal loss and effect of warm ischemia on the function of operated kidney. In our study, 99TmTc-DMSA isotope was used which is a static renal agent and allows accurate calculation of DRF (7). Since 99TmTc-DMSA scan provides relative functional percentage of the two kidneys and the contralateral kidney served as a control for comparison after LPN, we selected patients with normal contralateral kidney. Such selections have resulted in a young cohort of patients with mean age of $50.5 \pm 11.9$ years old in our study. The T-DRF was measured in all isotope studies. Any postoperative decline in T-DRF in the operated kidney was considered as a result of warm ischemia and ischemia-reperfusion injury combined with parenchymal loss. In nearly all postoperative studies, mean decline of T-DRF in the operated kidney was 7\%. In order to distinguish the effect of warm ischemia from the

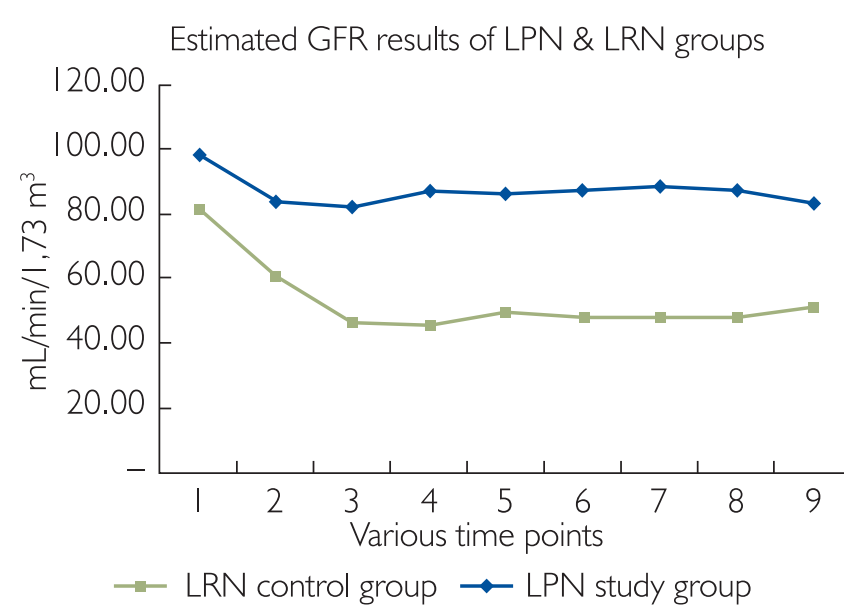

FIgURE 4: THE CURVES SHOW MEAN PREOPERATIVE (TIME POINT 1) EGFR AND MEAN RESULTS OF POSTOPERATIVE EGFR MEASURED IN PATIENTS WITH LPN AND LRN AT DIFFERENT TIME INTERVALS

(POINT 2: 5-6 HOURS POST-OP; POINT 3: $1^{\text {ST }}$ POST-OP DAY; POINT 4: $3^{\text {RD }}$ POST-OP DAY;

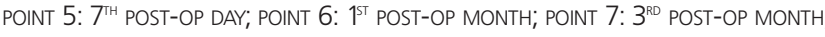
POINT 8: $6^{\text {TH }}$ POST-OP MONTH; POINT 9: $12^{\text {TH }}$ POST-OP MONTH)

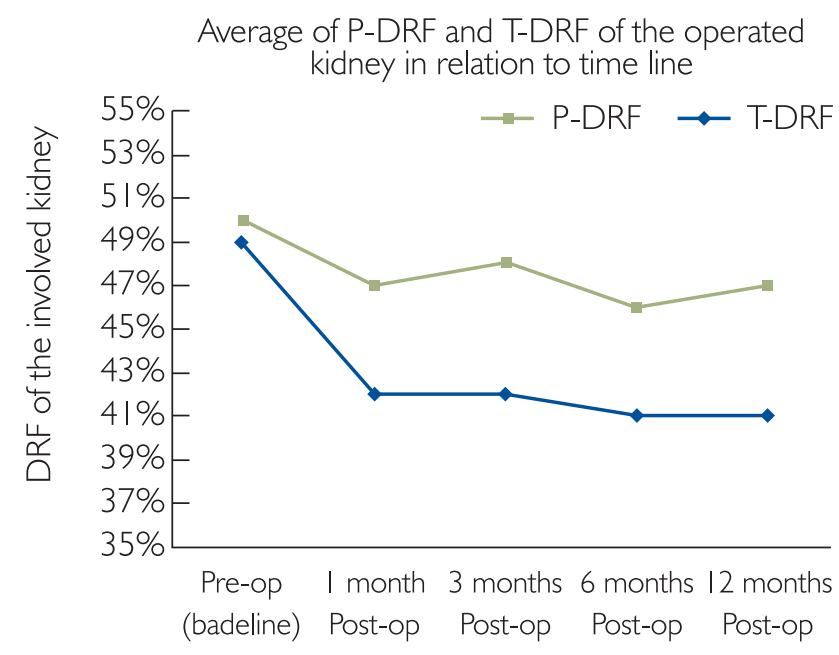

FIgURE 5: THE GRAPH SHOWS THE MEAN DECLINE OF BOTH P-DRF AND T-DRF OF THE OPERATED KIDNEY (LPN) IN THE STUDIED TIME INTERVALS

parenchymal loss, we introduced the so-called P-DRF in which a region of interest was selected on non-tumorous pole of the involved kidney and it was compared with the same region in the contralateral kidney.

Any postoperative functional decline in this intact pole of the operated kidney was considered to be as a result of warm ischemia and ischemia-reperfusion injury only. In our study, mean postoperative decline in the P-DRF of the operated kidney was only $3 \%$ which was found to be statistically insignificant ( $p$-value $=0.0727$ ). In agreement with the previous studies, we believe that within certain time limits of warm ischemia, which was $22 \pm 5.3$ minutes in our study, the ischemia- 
reperfusion insult may be negligible or reversible. On the other hand, deliberate parenchymal loss plays a major role in kidney function deterioration.

Warm ischemia and the IR injury to the kidney have been considered for a long time as the main factor related with postoperative renal function deterioration in patients undergoing PN under WI (1, 10-13). Several technically challenging techniques have been introduced for the reduction of $\mathrm{WI}(14,15)$. Nevertheless, the impact of renal parenchymal mass reduction was not distinguished from the effects of $W I$ and IR in the above literature. Parenchymal loss after PN occurs as a result of intentional tumor excision, some normal parenchyma resection and suturing. Thus, the mass or volume of the parenchymal loss should be considered and differentiated from IR injury when evaluating the renal functional outcome after PN.

Few authors have studied the impact of parenchymal volume reduction on renal function. In a large multicenter study cohort Shikanov and colleagues (16) assessed the influence of renal ischemia on long-term global renal function after LPN in patients with 2 functioning kidneys. They retrospectively evaluated eGFR of 401 patients with median tumor size of $25 \mathrm{~mm}$ and normal contralateral kidney who underwent LPN with median warm ischemia time of 29 minutes. Changes in early postoperative and nearly one year follow-up eGFR were $-16 \%$ and $-11 \%$, respectively. This result is nearly identical to our findings. The percent change in last eGFR was worse in patients with larger tumors suggesting that excising a larger lesion would result in more loss of renal parenchyma. Mir and colleagues (17) also reported that the preservation of the total renal function after PN ranged between $88 \%$ and $91 \%$ which reflects approximately $10 \%$ loss of the renal function (similar to our finding). Mir et al also showed that a higher reduction of the eGFR in patients with larger tumors which could be attributed to the excision of a larger lesions and the consequent greater loss of renal parenchyma. This was documented also by Sharma and colleagues (18) in 21 patients with solitary kidney who underwent partial nephrectomy due to small renal mass. Volume of the kidney was measured preoperatively and postoperatively by $C T$ scan and software with an automated segmentation algorithm. An average of 15\% parenchymal volume loss and $19.7 \%$ deterioration in kidney function were documented in mid-term postoperative period. They concluded that the percent of renal parenchymal volume loss was correlated with the percent loss in eGFR. It was shown that volume loss had a more direct, predictable effect on ultimate eGFR than ischemia time. A similar result was concluded by Simmons and colleagues (3) and also Song and colleagues (19). In the later study, diethylene-tetramine penta-acetic acid (99mTc-DTPA) was used for accurately estimating renal clearance and measuring eGFR by the kidney. They measured changes in individual renal function and investigated factors determining the degree of functional reduction in 65 patients who underwent LPN and 52 patients with open partial nephrectomy. In the entire cohort, renal volume re-

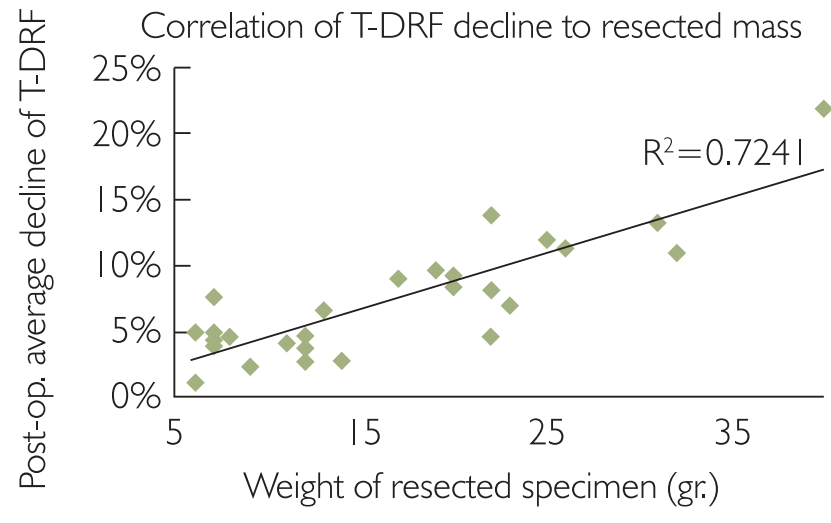

\section{Figure 6: COMPARING CORRELATION OF THE T-DRF DECLINE IN THE OPERATED KIDNEY TO THE MASS OF THE RESECTED SPECIMEN}

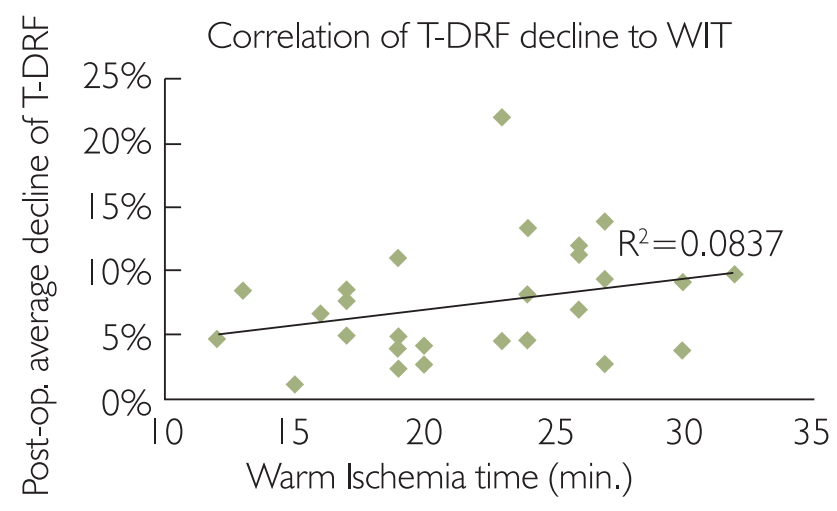

\section{Figure 7: CoMparing CORRELATION OF THE T-DRF DECLINE IN THE OPERATED KIDNEY TO WI TIME}

duction was the most significant, independent prognosticator for eGFR reduction after partial nephrectomy. Mir and colleagues (20) evaluated the role of volume preservation by introducing computed tomography volumetric analysis using free-hand scripting. The eGFR was measured by MAG3 in 92 patients who underwent partial nephrectomy. The authors revealed that the ultimate renal function after partial nephrectomy was primarily driven by parenchymal preservation with ischemia playing a secondary role as long as it was within a limited time period.

Current literature has not concluded to the most important factor for the renal function decline after PN and the contribution of $\mathrm{Wl}$ to the postoperative renal function has not been well documented (17). Some investigators advocated that the parenchymal mass preservation was stronger correlated to the functional recovery in comparison to the $\mathrm{Wl}(4,19)$.

The current prospective study aimed in distinguishing the impact of parenchymal loss from the Wl effect on the operated kidney. The 99mTc-DMSA isotope was used for the purpose due to the fact that it allows accurate calculation of DRF (7). The latter parameter was measured preoperatively and in dif- 
ferent postoperative intervals in 28 patients with solitary small polar tumours. Since 99mTc-DMSA scan provided relative functional percentage of the two kidneys, the contralateral kidney served as the control for the comparison after LPN Consequently, only patients with normal contralateral kidney were selected and a young patient population with mean age of $50.5 \pm 11.9$ years was eventually included in the study. Any postoperative decline in the T-DRF of the operated kidney was considered as a result of $\mathrm{Wl}$ and $\mathrm{WI}$ combined with parenchymal loss. In nearly all postoperative studies, a mean decline of $7 \%$ in the T-DRF was noted. In an attempt to distinguish the effect of WI from the parenchymal loss, the P-DRF was introduced. A ROI was selected on the non-tumorous pole of the involved kidney and was compared with the same ROI on the contralateral kidney. Any interference of the excision area to the ROI was prevented by including only patients with tumour mass of $\leq 4 \mathrm{~cm}$ in diameter located on either upper or lower pole of the kidney. Any postoperative functional decline in this intact pole of the operated kidney was considered to be as a result of WI only. The mean postoperative decline in the P-DRF of the operated kidney was only 3\% which was found to be statistically insignificant ( $p$-value $=0.072$ ). In agreement with the previous studies (21), it could be suggested that WI may result in negligible or reversible renal damage within certain time limits of WIT such as a mean WIT of the current study. In addition, the parenchymal loss seemed to play a more important role in kidney function deterioration than WI. Considering the above, it could be advocated that the LPN surgical technique could probably focus on the precise tumour excision and suturing rather than to the minimization of WIT. Nevertheless, additional studies are necessary for the confirmation of the above hypothesis.

Limitations of this study include the reliance on DRF and the use of the non-operated kidney as a stable reference unit before and after the surgery. Any postoperative compensatory hypertrophy of the contralateral kidney may result in a false outcome of DRF. Takagi et al. (22) showed that the compensatory hypertrophy of the contralateral kidney after PN remained rather limited and less than $2.3 \%$ in most cases. They conclud- ed that the larger the excised volume of the kidney, the more hypertrophy of the contralateral kidney was expected. The median tumour diameter of the latter study was $3.5 \mathrm{~cm}$ and probably resulted in higher volume loss in comparison to our series (median of $2.6 \mathrm{~cm}$ ). Hence, we assume that the compensatory hypertrophy may have been negligible in our study. Another limitation of our study was the lack of stratification of the results according to the length of the WIT or the tumour size. The parenchymal volume was never measured and the current study could not provide information regarding the pre-and postoperative changes in the volume of the renal parenchyma. Nevertheless, the changes in the contour of the operated kidney may influence measurements of the renal volume and the selection of ROls out of the excision field for measurements probably allowed for more reliable results. Moreover, the use of $\subset$ scans for the evaluation of renal volume would expose the patient in additional radiation without providing evidence that would significantly influence the results of the study.

\section{Conclusion}

In LPN, the parenchymal loss caused by the resection of the tumor and the suturing of the surrounding normal tissues resulted in kidney function deterioration which should be distinguished from WI effects. An average WIT of 22 minutes for a mean tumor diameter of $2.6 \mathrm{~cm}$ resulted in a $7 \%$ kidney function decline. $4 \%$ could be attributed to the parenchymal loss and $3 \%$ to $\mathrm{Wl}$.

The ultimate renal function after partial nephrectomy is primarily driven by parenchymal preservation with ischemia playing a secondary role as long as it is within a limited time period. One of the major implications of our study is that creating a bloodless filed by clamping the renal pedicle within certain time limits, and consequently precision of excision and renorrhaphy, should be a primary objective during any partial nephrectomy. This may result in more kidney function preservation than putting all efforts to decrease $\mathrm{Wl}$ time to zero while accepting all potential complications.

\section{References}

1. Becker F, Van Poppel H, Hakenberg OW, Stief C, et al. Assessing the impact of ischaemia time during partial nephrectomy. Eur Urol 2009; 56: 625-34. https://doi.org/10.1016/j.eururo.2009.07.016

2. Simmons MN, Schreiber MJ, Gill IS. Surgical renal ischemia: a contemporary overview. J Urol 2008; 180: 19-30. https://doi.org/ 10.1016/j.juro.2008.03.022

3. Simmons MN, Hillyer SP, Lee BH, Fergany AF, Kaouk J, Campbell SC. Functional recovery after partial nephrectomy: effects of volume loss and ischemic injury. J Urol 2012; 187: 1667-1673. https://doi.org/ 10.1016/j.juro.2012.02.1218 https://doi.org/10.1016/j.juro.2011.12.068

4. Song C, Park S, Jeong IG, Hong JH, Park HK, Kim C-S, Ahn H. Followup of unilateral renal function after laparoscopic partial nephrectomy. J Urol 2011; 186: 53-58. https://doi.org/10.1016/ j.juro.2011.03.021

5. Spaliviero M, Gill IS. Laparoscopic partial nephrectomy. BJU international 2007; 99: 1313-1328. https://doi.org/10.1111/j.1464410X.2007.06809.x

6. Levey AS, Stevens LA, Schmid $\mathrm{CH}$, Zhang $\mathrm{YL}$, et al. A new equation to estimate glomerular filtration rate. Annals of internal medicine 2009; 150: 604-612. https://doi.org/10.7326/0003-4819-150-9200905050-00006

7. Kibar M, Yapar Z, Noyan A, et al. Technetium-99m-N,Nethylenedicysteine and Tc-99m DMSA scintigraphy in the evaluation of renal parenchymal abnormalities in children. Ann 
Nucl Med 2003; 17: 219-225. https://doi.org/10.1007/BF02990025

8. Rutland MD. Origin of the Patlak-Rutland plot. Nucl Med Commun 1996; 17: 441. https://doi.org/10.1097/00006231-199605000-00015

9. Abeshouse BS, Lerman S. Partial nephrectomy versus pyelolithotomy and nephrolithotomy in the treatment of localized calculous disease of the kidney, with a report of 17 partial nephrectomies. Int Abstr Surg 1950; 91(3): 209-40.

10. Thompson RH, Lane BR, Lohse CM, et al. Comparison of warm ischemia versus no ischemia during partial nephrectomy on a solitary kidney. Eur Urol 2010; 58: 31-336. https://doi.org/10.1016/ j.eururo.2010.05.048

11. Choi JD, Park JW, Lee SY, et al. Does prolonged warm ischemia after partial nephrectomy under pneumoperitoneum cause irreversible damage to the affected kidney? J Urol 2012; 187: 802806. https://doi.org/10.1016/j.juro.2011.10.140

12. Parekh DJ, Weinberg JM, Ercole B, et al. Tolerance of the human kidney to isolated controlled ischemia. J Am Soc Nephrol 2013; 24 506-517. https://doi.org/10.1681/ASN.2012080786

13. Porpiglia F, Renard J, Billia $\mathrm{M}$, et al. Is renal warm ischemia over 30 minutes during laparoscopic partial nephrectomy possible? Oneyear results of a prospective study. Eur Urol 2007; 52: 1170-1178. https://doi.org/10.1016/j.eururo.2007.04.024

14. Gill IS, Patil MB, Abreu AL, et al. Zero ischemia anatomical partial nephrectomy: a novel approach. J Urol 2012; 187: 807-814. https://doi.org/10.1016/j.juro.2011.10.146

15. Nguyen MM, Gill IS. Halving ischemia time during laparoscopic partial nephrectomy. J Urol 2008; 179: 627-632. https://doi.org/

\subsection{6/j.juro.2007.09.086}

16. Shikanov S, Lifshitz D, Chan AA, et al. Impact of ischemia on renal function after laparoscopic partial nephrectomy: a multicenter study. J Urol 2010; 183: 1714-1718. https://doi.org/10.1016/ j.juro.2010.01.007

17. Mir MC, Ercole C, Takagi T, Zhang Z, Velet L, et al. Decline in renal function after partial nephrectomy: etiology and prevention. J Urol 2015; 193: 1889-1898. https://doi.org/10.1016/j.juro.2015.01.093

18. Sharma N, O'Hara J, Novick AC, et al. Correlation between loss of renal function and loss of renal volume after partial nephrectomy for tumor in a solitary kidney. J Urol 2008; 179: 1284-1288. https://doi.org/10.1016/j.juro.2007.11.071

19. Song C, Bang JK, Park HK, et al. Factors influencing renal function reduction after partial nephrectomy. J Urol 2009; 181: 48-53. https://doi.org/10.1016/j.juro.2008.09.030

20. Mir MC, Campbell RA, Sharma N, et al. Parenchymal volume preservation and ischemia during partial nephrectomy: functional and volumetric analysis. Urology 2013; 82: 263-268. https://doi.org/ 10.1016/j.urology.2013.03.068

21. Zargar H, Porpiglia F, Porter J, Quarto G, Perdona S, et al. Achievement of trifecta in minimally invasive partial nephrectomy correlates with functional preservation of operated kidney: a multi-institutional assessment using MAG3 renal scan. World J Urol 2016 Jul; 34(7): 925-31. https://doi.org/10.1007/s00345-015-1726-x

22. Takagi T, Mir MC, Sharma N, et al. Compensatory hypertrophy after partial and radical nephrectomy in adults. J Urol 2014; 192: 16121619. https://doi.org/10.1016/j.juro.2014.06.018 